\title{
Contending Masculinities and the Limits \\ of Tolerance: Sexual Minorities in Fiji
}

Nicole George

$\mathrm{F}_{\text {iji i }}$ is one of only a handful of states that has given constitutional recognition to the rights of sexual minority groups. ${ }^{1}$ This occurred in 1998 when a new constitution was enacted in the wake of a two-year process of public hearings and consultations, coordinated by an independent commission of constitutional review. ${ }^{2}$ While it was not a direct subject of public deliberation, the commission included in its report a recommendation that Fiji's Bill of Rights include a clause prohibiting discrimination on the basis of sexual orientation (Tarte 200I). Fiji's gay, lesbian, and transgender advocates hailed this move as progressive and visionary, anticipating a more accommodating future political environment as they pressed the case for further legal reforms. However, an almost immediate public backlash to these provisions from conservative indigenous nationalists and some of the country's most influential religious institutions indicated that such expectations were overly optimistic. As public criticism of the constitution's codification of sexual minority rights mounted, it became clear that Fiji was witnessing not a new and more tolerant era with regard to questions of sexual orientation, but rather a heightened level of controversy over the issue of same-sex relationships, and an increasingly powerful condemnation of those who choose to publicly demonstrate a homosexual or transgender identity.

The focus on male homosexuality has predominated in this debate, with many influential political actors framing discourses of masculinity in ways that uphold Christian standards of morality and describe tolerance of homosexual behavior as threatening the stability of key institutions in Fiji's society. However, these claims are frequently articulated in a highly selective manner. In this article I examine how contradictory and contending ideas about masculinity are voiced in the public domain in Fiji,

The Contemporary Pacific, Volume 20, Number I, I63-I89

(C) 2008 by University of Hawai' $i$ Press 
and discuss efforts undertaken by local gay activists to resist hegemonic constructions of masculine identity (Connell 2005, 77-83), like that promoted by conservative members of the political elite in Fiji.

I therefore describe how local and transnational influences have configured the spaces in which discourses of masculinity are articulated and contested. While ideals of Christian morality have been deployed to "delegitimize" homosexuality and subordinate homosexual men (Connell 2005, 78) by some church and political leaders in Fiji, the same actors have also sought to excuse violence perpetrated by indigenous males during the 2000 civilian-led coup in ways that suggest these acts were "authorized" (Connell 2005, 82-83) by a broader ethno-nationalist political agenda that aimed to secure Fijians' political dominance. ${ }^{3}$

I also examine how local gay activists have contested this scenario, drawing from my doctoral field research in Suva, Fiji, in 2002. At this time, my research focused centrally on the political agency of women's groups in Fiji. But as a result of volunteer work I conducted with one particular Suva-based organization, Women's Action for Change (WAC), I also came in contact with a number of male and female gay activists. My involvement with this community convinced me of the importance of documenting the strategies that enable politically vulnerable groups to stake a claim for recognition in a volatile and perhaps hostile environment.

Recent political developments have certainly made the predicament of gay activists—and particularly, gay men-precarious. Yet these men have also displayed some determination to promote homosexual identity in ways that challenge mainstream discriminatory attitudes. While overt and public political confrontation between pro- and anti-gay lobbies has generally not occurred (with sexual minority groups preferring to maintain a low political profile), as I show here, public manifestations of a gay rights agenda have recently become more forthright as activists have capitalized on strong support from transnational gay-rights advocacy networks. Nonetheless, representatives from many of Fiji's Christian churches continue to voice strong opposition to tolerance of homosexuality, their position of authority constraining the political space available to local activists pressing their claims for tolerance and state recognition of their rights.

\section{Conservative Forces and Anti-gay Rhetoric}

Historically, anthropologists' accounts of Pacific societies (undoubtedly shaped by their own attitudes to sexuality), "wiped clean from the pages" 
of their studies any discussion of the possibility of homosexual relations in Pacific Islands communities, and frequently concluded that homosexuality was absent (Herdt I997, ix-x). Yet, as later studies have shown, ${ }^{4}$ in many parts of the Pacific, homosexual activity has been authorized through ritual or in the cultural practice of gender liminality. ${ }^{5}$ Additionally, although it may not be conceded in an explicit fashion, a "boys will be boys" attitude to male adolescent homosexual experimentation has been noted in many Pacific social contexts (Besnier I994, 299; Schmidt 2003, 423). ${ }^{6}$

Despite this level of seeming acceptance, communities across the Pacific have generally responded unsympathetically to those who choose to articulate homosexuality as an essential and defining identity "trait." Commonly a differentiation is made between homosexual males who emphasize their sexuality in an essentialized or constant manner, articulating what Niko Besnier referred to as a "Western-style" gay identity (I994, 328), and gender-liminal males (see Alexeyeff, this issue), such as Samoan fa'afafine, Tongan fakaleiti, or Tuvaluan pinapinaaine. While they may be homosexual, gender-liminal males in Pacific contexts are deemed not to emphasize their sexual orientation as a fixed aspect of their identity but rather are seen to borrow a range of "social and cultural attributes and symbols" from the opposite sex in ways that are "foregrounded and backgrounded according to social context" (Besnier I994, 300,327 ). Moreover, the claim that there is widespread cultural acceptance of gender liminality in Pacific contexts is also problematic. Besnier described this tradition as "deeply embedded" in the cultures of various parts of the Pacific (I994, 299). Yet in Pacific contexts, shaped increasingly by industrialized modes of production, ${ }^{7}$ and a strong vein of "conservative Christian morality," it has been shown that gender liminal males often contend with processes of social marginalization and widespread levels of community ambivalence shown toward them (Schmidt 2003, 420, 426).

In Fiji, in contrast to many other Pacific Islands states, the social and political status of sexual minority groups has become the subject of intense public debate in recent years, particularly following the enactment of a new constitution and bill of rights in I998. On one side of the debate stands a nascent but cautious gay rights movement that has well-established relationships with many other activist organizations both within Fiji and across the Pacific Islands, particularly women's rights groups and organizations promoting AIDS awareness. Indeed, the gay rights movement in Fiji builds on the strong legacy of political activism that has been evident across the Pacific since the early I960s. Historically, civil society 
organizations in various Pacific Island countries have undertaken important campaigns on the local, regional, and international stage protesting against nuclear-weapons testing, and promoting gender equality, rights to political self-determination, social and economic justice, and democracy (Griffen I984, I987; Goodwillie and Lechte I985; Slatter 2006). Despite the volatility of Fiji's postcolonial political history, civil society activity in this setting has frequently seen organizations engage in highly provocative forms of advocacy that challenge the social and political status quo. This legacy has undoubtedly aided the emergence of a gay rights political agenda in Fiji. Since the late I990s Fiji's gay activists have become involved in campaigns protesting against discriminatory treatment of homosexuals and raising awareness on issues related to HIV/AIDS as well as providing counseling and support services.

On the other side of the debate stands a conservative and influential alliance of religious and political leaders who contend that the constitution's antidiscrimination provisions sabotage fundamental principles of morality. The commissioners involved in the constitutional review process that took place in the mid-I990s may have been motivated by a desire to see norms emerging in international conventions reflected in Fiji's constitutional law ${ }^{8}$ however, their efforts have provoked a volatile and frequently hysterical style of public debate that, ironically, appears to have intensified homophobic sentiment rather than promoted tolerance of homosexuality in Fiji. As one member of the activist community recently put it, "Anytime there is a positive result for sexual minorities, the gay and lesbian community in Fiji is further put at risk because of increased homophobia" (wAC/SM 2005a).

The most recent example of this fanaticism occurred in the wake of a Fiji High Court ruling (26 August 2005), overturning the conviction of an Australian tourist, Thomas McCoskar, who had originally been charged on sodomy offenses. ${ }^{9}$ Some leaders of Fiji's Methodist church responded to the High Court appeal process and ruling with a powerful wave of homophobic rhetoric. Their public statements included calls for support of public marches protesting against homosexuality (Radio Australia, $8 \mathrm{Nov}$ 2005; Fiji Sun, 23 June 2005) and claims that homosexuals should "be put to death and destroyed" (WAC/sm 2005b). One Methodist church protest organizer justified such actions by stating that condoning homosexuality would bring "our country" under "a curse." When asked to elaborate, he stated, "An example of a curse that could happen to our country, would be a tsunami like that which hit Indonesia" (Fiji Sun, 23 June 2005). 
At the highest levels of state, similar condemnations were made. While his tone may have been less vitriolic, Fiji Prime Minister Laisenia Qarase had, since 2003 , lent his own political authority to the campaign waged by those opposed to the constitutional provisions against discrimination. He consistently made public statements describing homosexuality as a sin and, in the wake of this most recent ruling, voiced his strong determination that homosexual sex would remain a prosecutable offense in Fiji (The Australian, I3 April 2003; WAC/SM 2005a). ${ }^{10}$

The prime minister's legal pronouncements, clearly informed by his Methodist faith, are indicative of how sites of authority are understood by most indigenous Fijians and how such convictions shape the terrain of national political debate. The Methodist church (lotu) enjoys a powerful position among indigenous Fijians, as one of three intersecting institutions that regulate the lives of Fiji's peoples; the majority privilege the lotu alongside the vanua (land, or traditional Fijian community), and the matanitu (state) (Ryle 2005, 58). ${ }^{11}$ However, as indigenous nationalist sentiment has risen in recent decades, so has the view that the normative authority residing in the lotu and vanua should simply be transposed onto the regulatory structures of the state. As one Fiji observer has argued, for the majority of indigenous citizens, the "dictum" $\mathrm{Na}$ vanua na lotu, na lotu na vanua (The Church is the land, the land is the Church) has regularly inspired calls from Fijian nationalists that Christian ideals be institutionalized at the state level, and, in their most emphatic form, that Fiji declare itself a Christian state (Tuwere 1997, 47; see also Niukula I997; Ryle 2005). ${ }^{12}$ These considerations help explain the political influence wielded by those conservative religious and political leaders aiming to "delegitimize" homosexuality in Fiji.

Indeed, within only a week of the constitution's coming into effect in I998, heated debate on its provisions for sexual minorities emerged. At this time outspoken government backbencher Pastor Joeli Kalou was one of the first to challenge the legitimacy of the provisions, arguing that the constitution had to be amended because it sanctioned same-sex marriage. The Methodist church and the Fiji Council of Churches also acted quickly on this issue, circulating petitions opposing homosexual marriage that were later presented to the government (Radio Australia, 4 Aug I998). The attorney general acted to quell these concerns, arguing that the constitution did not give legal recognition to same-sex marriages (Radio Australia, 7 Aug I998). However, in response to increasing pressure, the government capitulated and promised to draft an amendment (Tarte 200I, 530). 
In I999, Fiji experienced a change of government, which brought a Labour Coalition to power, led by Fiji's first Indo-Fijian prime minister, Mahendra Chaudhry. This government continued with the programs of constitutional amendment begun by the previous incumbents and also vowed to overturn the provision on sexual orientation. Newly elected Attorney General Anand Kumar Singh justified these actions on the basis that the provisions had not been sufficiently debated during the process of constitutional review and that there was a need to "reinforce certain values ... held by the majority of the population" (Fiji Times, 22 Feb 2000). His proposed amendment therefore listed "unnatural offences, indecent assaults and indecent practices" as prosecutable acts (Radio Australia, 22 Feb 2000; Daily Post, 23 Feb 2000), and defined marriage as the "union of one woman and one man, to the exclusion of all others" (Strubbe and Tora 2002).

These government efforts, designed to ensure that homosexual acts remained criminal offenses, were supported by Fiji's mainline and Pentecostal Christian churches. Waisea Vuniwa, president of Fiji's Seventh-Day Adventist church, contended at this time that homosexuality was "sinful and evil and ... should not be condoned." His declaration that such sexual freedoms should be curbed by the "moral principles and standards given to us by God" (Daily Post, 22 Feb 2000) once again invoked the legitimacy of a union between the Church and State in Fiji.

In this political environment, entering the debate on the side of sexual minority groups required careful rhetorical framing, for such actions could easily be portrayed by more parochial interests as an attempt to undermine structures of authority. Representing the newly formed Fiji Human Rights Commission established by the 1997 constitution, Justice Sialosi Kepa framed his views on the subject in legal terms. Kepa argued that the government's proposed amendments would contravene provisions of the constitution and common law in relation to individuals' rights to privacy (Daily Post, 22 Feb 2000), and were potentially in conflict with international human rights norms. Indicating the damage that would be done to Fiji's international reputation if the provisions relating to sexual orientation were removed, he argued, "Fiji has a good human rights record internationally and this image will be tarnished if the government goes ahead with its proposal to remove the rights of a section of the population in this way" (Daily Post, 22 Feb 2000).

Members of the nongovernmental organizations community and, in particular, Women's Action for Change, which had established a Sexual 
Minorities Project (WAC/SM) in I998, also voiced opposition to the proposed amendments in ways that sought to avoid inflaming indigenous sensibilities by clashing with Fiji's Christian churches. The WAC project also drew attention to the international dimensions of these questions by highlighting the negative economic ramifications that might follow if the government continued to promote the criminalization of homosexual activity. WAC coordinator Peni Moore argued that while Fiji was keen to portray itself as a gay-friendly destination in the international tourist market, it was ironic that it was also considering removing legal protection for its own homosexual citizens. Commenting on the fact that local carrier, Air Pacific, had taken out advertisements during Sydney's Mardi Gras, Moore warned that if the proposed amendments went ahead an international boycott of Fiji by the gay community was imminent, something that would surely be damaging to Fiji in economic terms (Daily Post, I I April 2000).

\section{The 2000 Coup}

While local activists were at this point conscious of the need to pursue a cautious political path as they voiced their support for the constitution's antidiscrimination provisions, events occurring in mid-2000 dealt the movement a substantial blow. Although not directly represented in the "Peoples Coalition" government, conservative representatives of the Christian churches and members of the indigenous establishment remained influential sideline political players, acting to fuel suspicions that Prime Minister Chaudhry was formulating policies designed to promote an "Indian takeover and anti-Fijian agenda" (Robertson and Sutherland $200 \mathrm{I}, 7)$. It has also been alleged that representatives from these ranks lent behind-the-scenes support to a group of nationalist insurgents who, in May 2000, plunged Fiji into political crisis by invading Fiji's parliamentary complex, taking a number of government members hostage, and eventually establishing their own Fijian-led regime (Robertson and Sutherland 200I; Fraenkel 2000; Fry 2000).

During the ensuing days of tense negotiations between the rebels, Fiji's military, and the Great Council of Chiefs, waves of violence swept Suva and many outlying regions of Fiji. In the first day of the coup alone, incidents of looting (photo I), arson, rape, vandalism, and occupation saw F $\$ 30$ million of damage in Suva's central business district. In part, these incidents were spontaneous reactions to the rebels' actions, and in part, 
they reflected a coordinated and sustained campaign by nationalists to weaken state authority and spread fear throughout the population (Robertson and Sutherland 200I, Xv-I7; Emde 2005; Cretton 2005; Kaplan 2005). Much of this violence was racially targeted and included the occupation of Indian-held leasehold farms and Indian private businesses. In isolated settlements in the Tailevu and Naitasiri provinces near Suva, the violence was so serious that Indo-Fijian refugees began heading toward camps in the vicinity of the western city of Lautoka to seek protection from "marauding gangs of Fijians" (Robertson and Sutherland 200I, 28). At the same time, the nationalist rebels in control of the Parliament coordinated sustained and violent raids, which targeted areas of Suva in an indiscriminate manner in order to keep "the city on edge" (Robertson and Sutherland 200I, 25). As the political standoff continued, violence became more brazen, with the coup conspirators demonstrating to their adversaries their capacity to wreak coordinated havoc by increasingly targeting public infrastructure and industrial sites (Robertson and Sutherland 200I, 23). Nationalist rebels seized the Monasavu Dam, which provided Suva with hydroelectricity, and the capital city was plunged into chaos as its power supply was also held hostage. Around the country, police stations came under siege, as did telecommunications infrastructure, army bases, tourist resorts, a tuna cannery in Levuka, the Fiji Water bottling plant at Rakiraki, and regional airstrips (Kaplan 2005). The rebels went as far as threatening to take over Nadi's international airport and the Central Police Station in Suva.

Television and newspaper reports of these events were filled with images of an armed, rebel, indigenous militia, concealing their identity with dark sunglasses, hats, scarves, or balaclavas, and frequently engaging in incidents of open conflict with police and military. While women were also involved in some early incidents of looting, the overwhelming images of the more serious violence that occurred during this period suggested a model of hypermasculine behavior that was uncompromising, and drew strength from its collective force.

After fifty-six days, the hostage crisis and coup standoff was resolved. The chief perpetrators were charged and placed in custody, an interim pro-nationalist government was established, and Fiji was restored to an uneasy calm. But even though the violence that had destabilized many areas of the country and challenged the authority of the state's discipline forces was roundly condemned by the new political administration, the perpetrators of the violence-the gangs of men who had played key desta- 


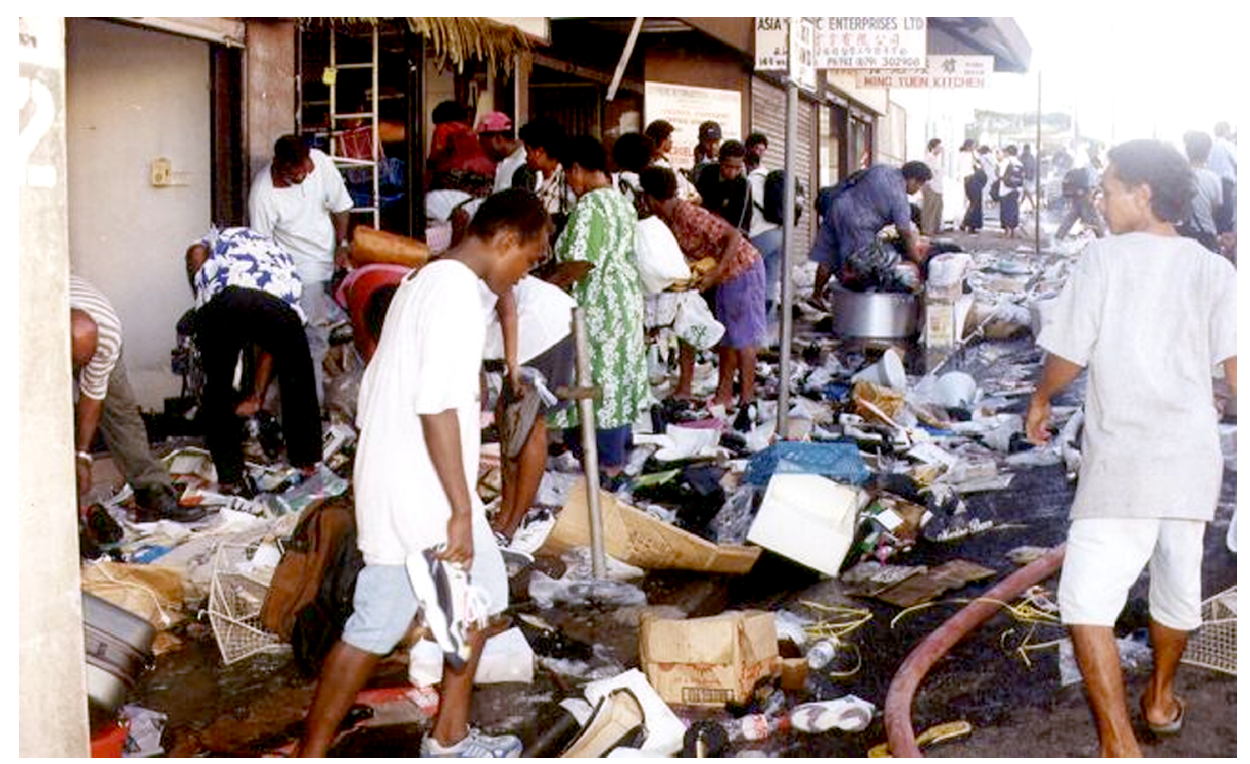

Рното г. Looting Central Suva, I9 May 2000. Reproduced courtesy of Litiana Waqalevu.

bilizing roles-for the most part, escaped retribution. While investigations into the activities of more than two hundred fifty rebel supporters began at this time, efforts focused primarily on identifying sympathizers within the military. In order to reduce tensions, the interim government emphasized reconciliation and national unity over retribution, moves that ultimately meant that aside from those more directly implicated in the coup leadership, the majority of those charged with lesser coup-related offenses received lenient treatment. ${ }^{13}$

The moderate nature of the response to such a widespread display of lawless activity was evident from the earliest days of this political crisis. While Ratu Mara, the incumbent president, described the violence occurring in Suva on 20 May as Fiji's "shame" (Fijilive, 2I May 2000), comments of others implied that these events could be justified as legitimate responses to political grievance or manipulation. For example, in an interview comparing his actions in 1987 with those of the coup leaders in 2000 , former Prime Minister Sitiveni Rabuka's description of the waves of looting and arson in Suva suggested that he saw these acts as understandable or natural. He stated that "those actions ... could have been carried out by any race in the world in a similar situation. It was just straight forward" (Fiji Times, 22 May 2000). 
The Reverend Josateki Koroi, a political moderate and former head of the Methodist church, called on the looters to repent, but even he seemed eager to provide some justification for the lawless behavior taking place around the country. While Koroi argued that looters must return the stolen goods and help clean up the damage done in the wake of the rioting, he also suggested that the Methodist church examine its own responsibility for these actions. Diminishing the personal responsibility of the rioters, he pointed to the influence of recent church leaders, who, he argued, had preached a "gospel of racism, culturalism and the superiority of the Fijian race over others contributing to hatred" (Fiji Times, 24 May 2000).

It is therefore not surprising that these events exist in the collective memory of many young Fijian men who live in and around Suva as comparable to "Christmas," a period when it became justifiable, even legitimate, to help yourself to what you wanted (Pita Sipeli, pers comm, 5 Nov 2002). The general lack of contrition has prompted some local observers to express the fear that these attitudes will contribute to a "coup cycle" in Fiji (Carling and Peacock-Taylor 200I, 27), in which models of violent masculinity become hegemonic among young Fijian males who, encouraged by the view that lawlessness pays, and led by the examples of 1987 and 2000 (and later 2006), are convinced that Fiji is "theirs" and they can do "whatever they want to other people" (Durutalo I997, quoted in Monsell-Davis 2000, 219). Yet in the postcoup political environment this conduct appears to have been authorized by sympathetic political and religious leaders, eager to portray it as an understandable collective manifestation of ethno-nationalist grievance.

Certainly it could be argued that the level of civil chaos created by such hypermasculine activity served the interests of Fiji's indigenous ruling classes and their ambitions to retain power. Thus it is hardly surprising that, in the aftermath of these events, Fijians participating in this activity were treated leniently. At the same time, efforts to legitimize or at least condone this type of behavior perhaps also reflected racialized conceptualizations of masculinity that have local currency. As Teresia Teaiwa noted, while service in Fiji's military has been seen in both historical and contemporary settings as a "bastion" of indigenous masculine identity and a source of social prestige, the lack of an Indo-Fijian presence in Fiji's armed forces has been used as a pretext to question Indo-Fijian masculinity (2005, 206, 210). The violence perpetrated against the Indo-Fijian community in May and June 2000 was perhaps also "naturalized," reflecting the long-held 
view of Fijian men as aggressors and the masculinity of Indo-Fijian men as subordinate by comparison.

Most striking, however, are the contrasts between efforts to authorize this lawless and violent masculine behavior, and the intolerance demonstrated by Fijian conservatives toward masculine homosexuality. As outlined earlier, influential political and religious figures have not hesitated to describe the threats posed to Fijian institutions should homosexuality be condoned. Indeed, in its most vitriolic form, their homophobic rhetoric has described physical threats such as tsunamis or spiritual punishments as curses that will be visited on Fiji if homosexuality is tolerated.

Certainly the general prevalence of violence during this period inclined sexual minority groups to feel uneasy about their personal security. ${ }^{14}$ And political developments in the months after the 2000 coup increased their feelings of vulnerability and forced the gay activist movement in Suva to adopt a low profile. The interim regime formally abrogated the I 997 constitution, and put in place plans to establish a new constitution that might encapsulate the union between matanitu, vanua, and lotu in ways that were more acceptable to indigenous nationalists. While the Fiji Court of Appeal ruled in March 200I that this abrogation was legally invalid, stating that the 1997 constitution and the institutions it established to protect the rights of citizens remained intact ( $\mathrm{Lal} 2003$ ), nationalist opposition to the 1997 constitution remained formidable (Robertson and Sutherland $200 \mathrm{I}$, II3). In a political environment in which prominent figures continued to voice sympathy for the coup perpetrators' nationalist aims, and interim Prime Minister Laisenia Qarase publicly articulated the view that he was in power because it was "God's plan" (quoted in Michael Field 2002), the domestic political space available to activists aiming to promote a gay-rights agenda was severely constrained.

The June 200 I murder of John Scott, a Fijian of British descent, and his longtime partner Gregory Scrivener, was an event that again demonstrated the subordinate status of homosexual males in Fiji. As the head of the Red Cross in Fiji, Scott was a prominent figure in Suva who was open about his sexuality and was viewed by many in that city's gay community as a "positive role model" (Pita Sipeli, quoted in the Daily Post, 5 July 2002). Scott had also played an important role in the hostage-taking episode that occurred in Fiji's parliamentary complex during the 2000 coup, bringing supplies and coordinating medical treatment for government representatives held captive by the nationalist rebels (photo 2; Scott 2004, 30-36). 
Early speculation on the motivations for this particularly brutal crime, which the local media reported with a sensationalist attention to detail, centered on Scott's coup involvement (Scott 2004, I09; Robie 2003, 4). The dead men had "feared for their lives," reported the BвC on 2 June $200 \mathrm{I}$, as their family members and commentators from around the region speculated on possible political motivations for their murders (Pacific Islands Report, 2 July 200I; Robie 2003, 4). Rumors had been circulating that Scott was to be called as a state witness in the upcoming trial of the coup perpetrators and would be well-placed to incriminate as yet unidentified, but highly placed, nationalist conspirators (Strubbe and Tora 2002).

As investigations into the murders continued, however, the issue of Scott's and Scrivener's homosexuality began receiving more concentrated attention. Media and police reports began to focus on the victims' alleged

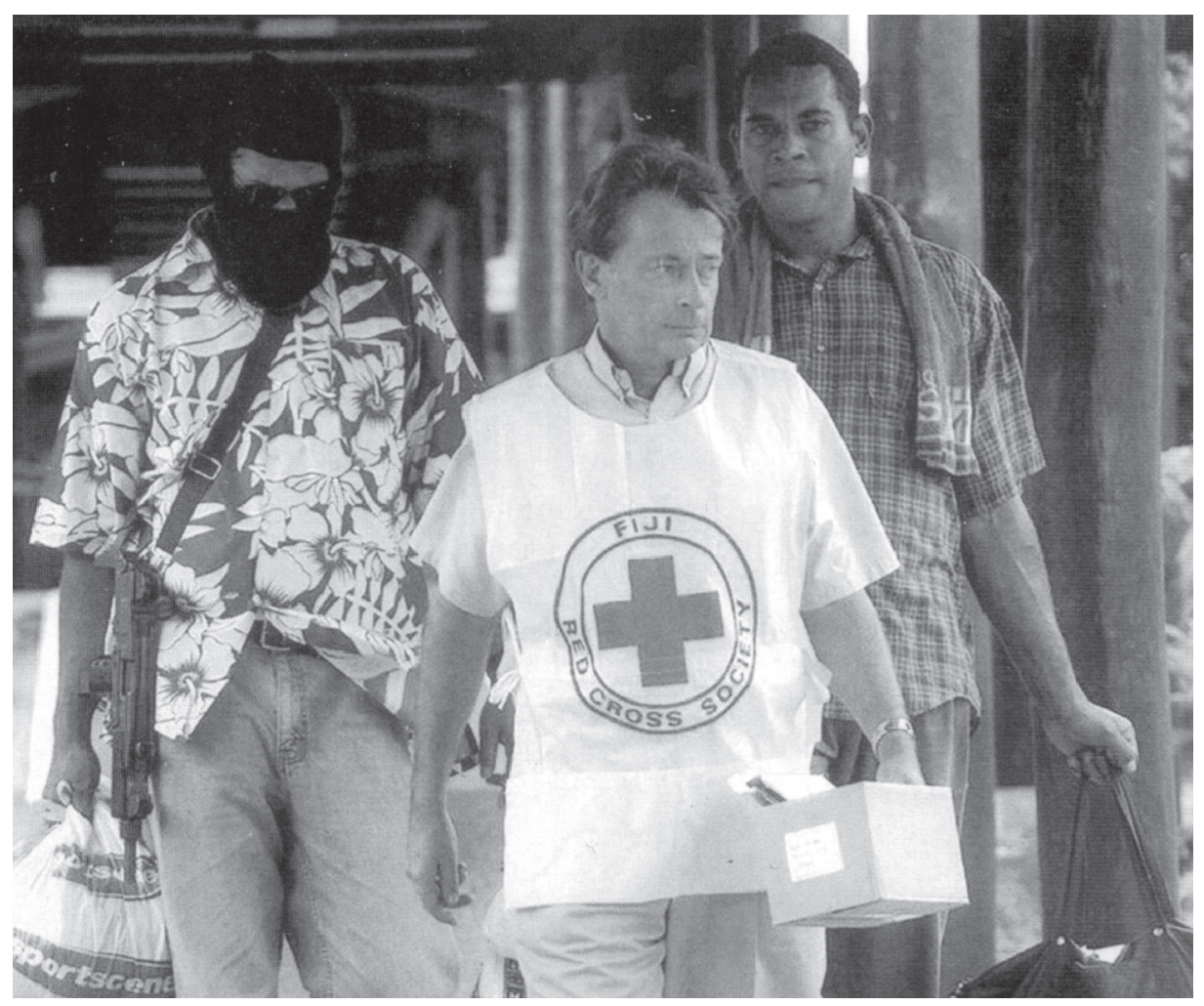

Рното 2. John Scott being escorted into the parliamentary compound. Reproduced with permission of the New Zealand Herald/APN. 
drug use and solicitation of minors, and likened the dead couple's behavior to that of sexual predators (Sydney Morning Herald, Io July 200I). Throughout their investigations, Fiji Police Commissioner Isikia Savua, a figure allegedly deeply implicated in the coup conspiracy (Robertson and Sutherland 200I, I6), repeatedly demonstrated a strong level of prejudice against male homosexuals (Scott 2004, II2). On one occasion he stated that the brutality of this crime suggested a "personalized killing" motivated by "vengeance, anger, and hurt" and reflecting "lifestyle" rather than politics (quoted in Strubbe and Tora 2002). In a later interview for New Zealand television, Savua again demonstrated this prejudice, stating: "People are focusing on the good side of Mr Scott and his partner Greg. But people tend to forget that he's a practising homosexual. . . . I don't profess to understand everything about homosexuality, it's just that they tend to be more vicious than the normal heterosexual relationship" (quoted in Scott 2004, IIO-I II).

After the perpetrator of these crimes gave himself up to the police, Commissioner Savua went to the extraordinary lengths of providing a defense for the prime suspect, again raising allegations of Scott's and Scrivener's sexual solicitation, and suggesting that the accused was "incensed by the way he and other young people had been exploited to fulfill the sexual desires of his two victims" and felt an "intense hatred of Mr. Scott" (Radio Australia, 2 Aug 2002). ${ }^{15}$

Fiji's police and media engaged in a collaborative effort to vilify Scott's public reputation through a range of unsubstantiated allegations during this period (Scott 2004, I 48), a development that increased the vulnerability of sexual minority communities at a broader level. ${ }^{16}$ Young gay men in Suva experienced heightened feelings of insecurity and fear (Pita Sipeli quoted on Radio Australia, I July 200I) as they came to terms with yet another episode in which homosexuality was being condemned in a vitriolic fashion and attempts were being made to legitimize a serious violent crime. However, while local gay activists were extremely conscious of the consequences that would necessarily follow in the wake of this negative public interest, they also felt that this was not the time for political confrontation (Carlos Perera, pers comm, 26 Feb 2002). Consequently, for a number of months, the community of gay activists in Suva became almost politically invisible. While they frequently lent their support to the political campaigns undertaken by nongovernmental organizations working on human rights and gender concerns, they avoided activity that focused on a gay rights platform and concentrated principally on strengthening inter- 
nal networks to provide counseling and sexual health advice. Many in the community even adopted a more conservative style of dress so as to become less readily identifiable in the street (Carlos Perera, pers comm, 6 April 2002). ${ }^{17}$

\section{Renewed Confidence}

Events taking place internationally during 2002 generated a renewed level of confidence among the community of gay activists in Fiji. In particular, preparations for participation in the Gay Games held in Sydney in October of that year increased a determination among young gay men to once again begin to assert a more pronounced public profile. As local activists engaged in the difficult task of raising funds to cover the costs of participation, and prepared presentations for the various forums that would be held in conjunction with the games, enthusiasm for political engagement on a variety of levels began to emerge once more.

In April 2002, for example, I attended a fund-raising barbecue hosted by the Women's Action for Change Sexual Minorities project. When I commented on the vibrancy and energy evident during this event, which contrasted significantly with the heavy atmosphere that had seemed to pervade WAC/SM meetings I attended in previous months, a number of activists informed me that the gay community in Suva "was back." However, while these events were "faithfully supported by close family and friends of the gay community" (Fiji Times, 28 Oct 2002), there was also a widespread reluctance among potential local benefactors to develop a public association with sexual minority groups. This ultimately meant that while the Gay Games organizers had awarded scholarships to twentytwo representatives from Fiji to attend the games, only eight applicants had the financial resources to attend. Nonetheless, the international profile of this event, and the local and international press coverage of Fijian participation (Fiji Times, 28 Oct 2002; Sydney Morning Herald, I I June 2002), provided an important and nonprovocative platform from which the gay rights agenda might be relaunched, and contrasted in significant ways with the volatile political environment that had surrounded questions of male homosexuality in the previous twelve months.

In October 2002, male gay activists in Suva displayed a new strategy, which, although subtly framed, can be read as an attempt to bring questions of sexual orientation into the political mainstream. At this time, a number of indigenous gay activists began to wear the sulu, a tailored wraparound garment generally worn as formal attire by Fijian men. Although 
it was introduced to Fiji by early Christian missionaries (Hereniko 2003, 78 ), the sulu has become synonymous with the institutions that regulate life in the indigenous community. Worn by Fijian boys, it features as part of the uniform in many of Fiji's schools. It is also frequently worn by indigenous members of Fiji's police force and military. Among the indigenous establishment the sulu is the formal garment of choice, worn in public by Methodist church ministers, indigenous parliamentarians, and members of Fiji's Great Council of Chiefs. Indeed, the political value of the sulu as a garment suggestive of indigenous identity has been noted by Robbie Robertson and William Sutherland, who argued that during the 2000 coup, this garment served as a "circuit breaker" for rebel leader George Speight (photo 3), who attempted to assuage Fijian conservatives' mistrust of his mixed-race origins by always appearing in the parliamentary complex immaculately dressed in a shirt, tie, and formal sulu (Robertson and Sutherland 200I, I3).

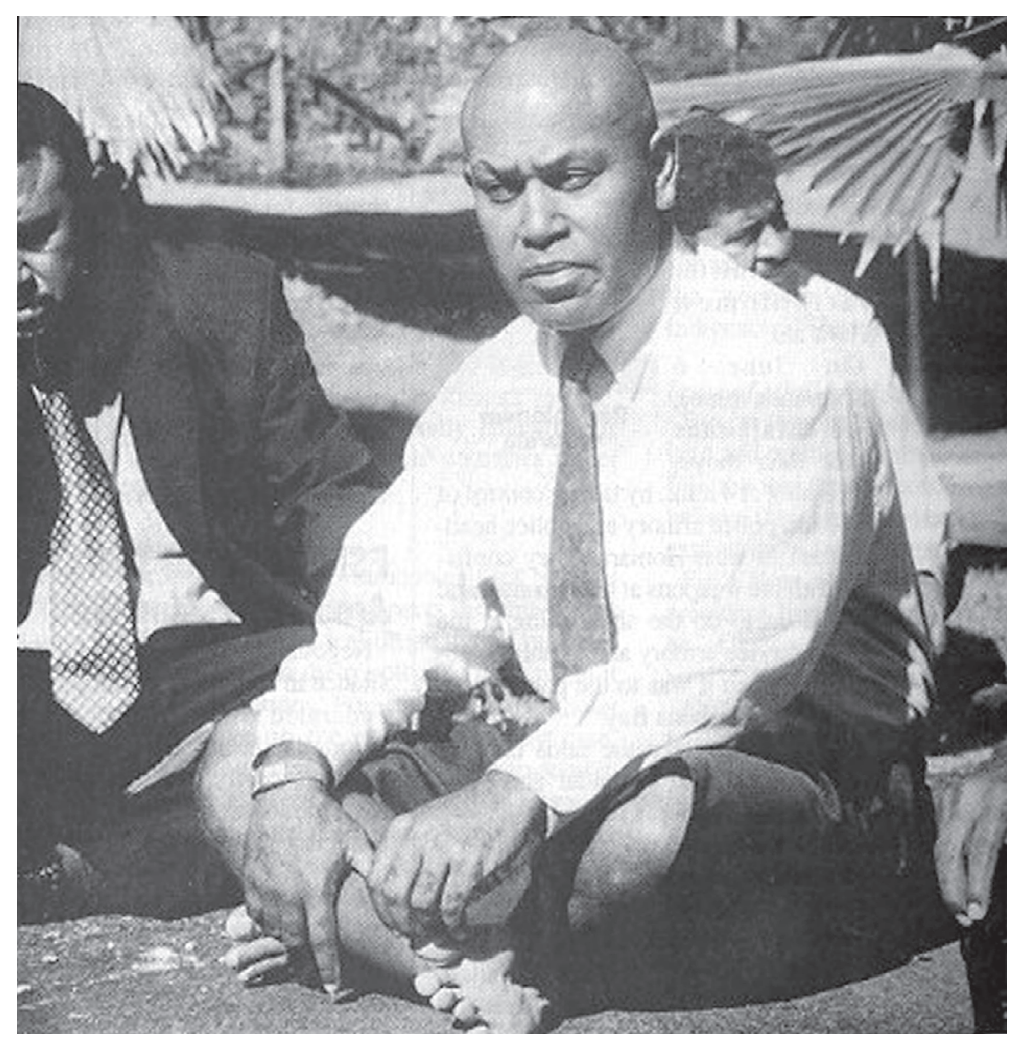

Рното 3. 2000 coup leader George Speight, parliamentary complex, Suva. Reproduced courtesy of Islands Business Magazine. 
But if indigenous gay males in Suva were also using the sulu as a "circuit breaker" in 2002-or as they tended to argue, "reclaiming the sulu"they were doing so in a way that challenged conventional ways in which the sulu was worn, by adopting a highly individual look. For example, one activist frequently teamed his sulu with a T-shirt featuring an image of Che Guevara and a cowrie-shell necklace (photo 4). Others sought to develop the shirt, tie, and sulu paradigm, by wearing the sulu with I97osstyle shirts featuring wide stripes, bold colors, and vintage-width collars, procured from Fiji's many secondhand clothing shops. In conversations on where this trend might lead, local activists floated the prospect of making sulu out of denim, and even toyed with the idea of appliquéd flame motifs.

The symbolism that is part of these efforts to reclaim the sulu, to my mind, has an important political significance. By attempting to individualize the way in which the sulu is worn, I would argue that these activists were able to challenge mainstream conceptualizations of indigenous iden-

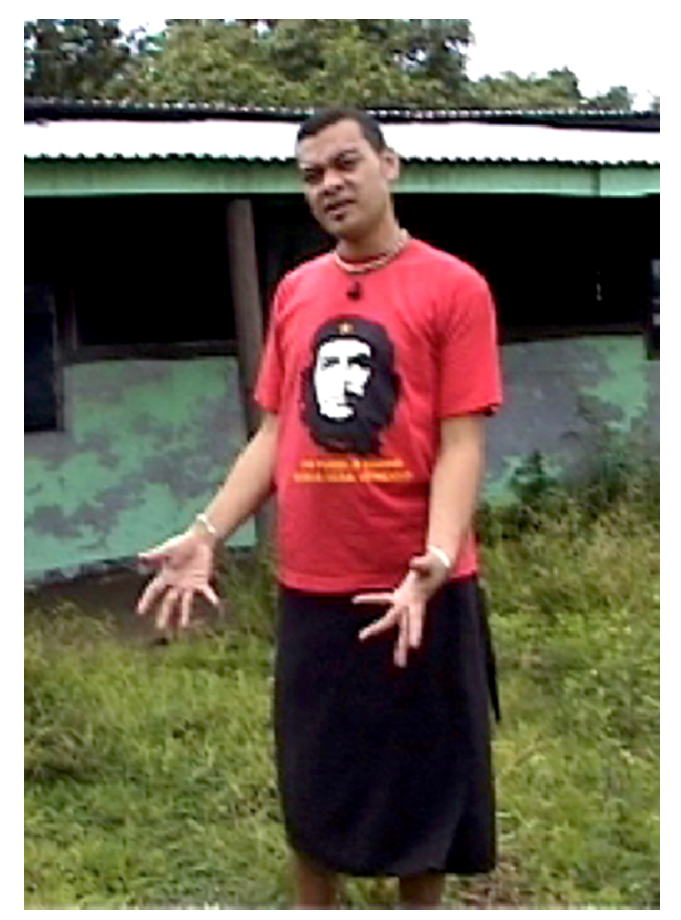

Рното 4. Pita reclaiming the sulu. Photo by author, 30 October 2002. 
tity, and particularly, sites of Fijian authority that have consistently sought to subordinate certain varieties of masculine behavior. Deinstitutionalizing the sulu, by teaming it with more unconventional items of clothing, can be read as a symbolic challenge to the hegemonic sites of indigenous institutional authority, and a simultaneous demand that indigenous diversity be afforded a more significant degree of mainstream recognition.

Developments occurring in late 2005 indicated that gay activism in Fiji may have come "back" in more forthright terms. In response to inflammatory comments made by members of the Methodist church concerning the legal status of homosexuality, WAC/SM members publicly stated that such sentiments "should be stopped" because they "increase the fear in the lives of the members of the gay community and ... the level of violence and abuse perpetrated against the members of the gay community" (Radio Australia, 8 Nov 2005). In this period they also argued that religious institutions and public figures, including the prime minister, should "consider issues in their entirety" and desist from highlighting these questions "for their own personal or political gains" (WAC/SM 2005b). At a Pan Pacific regional HIV/AIDs conference staged in New Zealand in November 2005, this trend continued when Fijian gay activists drew international attention to the activities of the Fiji Methodist church, which they described as the most serious promoter of homophobia in Fiji (NZ AIDS 2005). The courage of this vocal public stand was recognized in early 2006 when the WAC Sexual Minorities project, coordinated by Carlos Perera, was awarded a human rights award for its work in Fiji by a UNDP-sponsored program that aims to promote advocacy and education on human rights issues in the Pacific (Fiji Times, 22 Feb 2006).

\section{New Contingencies: December 2006}

Fortunes altered again in December 2006 as Fiji suffered its fourth coup in less than twenty years, this time led by Fiji's military commander. Commodore Voreqe Bainimarama defended his overthrow of the country's democratically elected government on the grounds that the incumbents had, since 2000 , promoted a self-serving culture of political corruption and indigenous partisanship that threatened to have "very serious consequences for [Fiji's] future generations" (Bainimarama 2006). Almost immediately, the military made it clear that any public opposition to its actions would be viewed as an effort to promote public resistance to the coup and would elicit grave consequences (Bainimarama 2006). These threats were 
not idle. There have since followed widespread reports of the military's verbal and physical intimidation of political figures, news reporters, activists, lawyers, businesspeople, and academics who have made public statements against the current regime. ${ }^{18}$ Claims of human rights violations by Fiji's military and police currently number into the hundreds. ${ }^{19}$

While civil society groups in Fiji have questioned the lawfulness of such tactics of intimidation (Daily Post, 2 March 2007; Fijilive, 25 Jan 2007), in broader terms reactions to the latest coup in Fiji have been mixed. Here an interesting split is revealed between groups committed to a pro-democracy agenda who are opposed to the coup,,$^{20}$ and organizations engaged in efforts to promote social justice in Fiji and who identify closely with the military-led regime's stated goal to "clean up" corruption (political activist, pers comm, 6 Feb 2007). ${ }^{21}$ What is certainly clear, however, is an emerging consciousness among all civil society groups, including those committed to the promotion of a gay rights agenda, that they now operate in an authoritarian political climate where opposition invites intimidation. This new set of political contingencies is viewed by many as warranting a cautious tone in public debate and the need for careful appraisal of the risks involved when articulating political demands in the public domain. As one longtime activist put it, "We know from our experience in ' 87 , you can't be naive in these circumstances. You have to be aware of the risks of speaking out" (pers comm, 4 Feb 2007).

While the military-led government could certainly be accused of encouraging self-censorship within civil society in Fiji at the current moment, and of once again reinforcing the relationship between hegemonic masculinity and militarization, some of the new regime's actions might also be viewed, somewhat ironically, as strengthening the hand of gay activists in Fiji. For example, the military has been sharply critical of Methodist church leaders who have condemned their actions as "treasonous acts against the state" (Radio New Zealand International, 6 Feb 2007) and even called church leaders into military barracks for questioning over such statements (Fijilive, 6 Feb 2006). Such challenges suggest a reordering of the sites of authority traditionally viewed as important to the lives of indigenous Fijians. ${ }^{22}$ In the longer term, this may weaken the normative influence that the Methodist church has held over the state, particularly regarding the status of homosexuality in Fiji. At the same time, despite the unconstitutional nature of the military takeover in December 2006, the new regime has stated on numerous occasions its commitment to upholding the 1997 constitution, with all provisions and constitutional institutions intact. This 
suggests that the constitutional rights of Fiji's homosexual citizens will remain protected for the moment at least. Whether such developments will provide sexual minority groups with a more secure platform from which to contest their political subordination into Fiji's uncertain political future remains to be seen.

\section{Conclusion}

In this article I have shown how conservative members of Fiji's political elite have selectively privileged ideas about masculinity in the public domain. Tolerance of male homosexuality is often construed as posing a threat to the integrity of the key sites of authority that regulate indigenous society. Yet other forms of masculine behavior that have, at times, represented a far more tangible threat to security thanks to their lawless and violent aspect, have not been ascribed the same malevolent status. Indeed, as I have demonstrated, members of the political elite have often appeared eager to authorize violent forms of masculine behavior, by excusing it as a legitimate or justifiable response to political grievance or manipulation.

Although the rights of Fiji's sexual minorities have been codified in the country's constitution, the trends described here have clearly eroded the political will required to safeguard these provisions. This has meant that, at various points, activists contesting the subordinate political and social status of homosexuals in Fiji have been forced to operate in a severely constrained political space. At times, they have adopted a low political profile in the face of determined resistance, but on other occasions they have engaged in more creative, sartorial strategies of political action.

Certainly there was some evidence to suggest that in late 2005 , gay rights activists had begun to engage in a more forthright style of political engagement on questions of discrimination, aiming to draw domestic and international attention to their cause. However, only twelve months later, there followed another substantial shift in the political climate as a military-led regime toppled the elected government from power. These events saw civil society actors, including gay activists, generally assume a more cautious political posture operating, as they were, in an authoritarian context. It is perhaps somewhat ironic therefore that some of the military government's actions might also be read as sympathetic to the gay rights cause. In the long run, it remains to be seen whether the actions of this new regime will be enough to break the political stronghold of those conservatives who, for nearly a decade, have made concerted efforts to 
ensure that the limits of tolerance regarding acceptable masculine ideals remain narrowly defined in Fiji.

* $\quad * \quad *$

I would like to thank Margaret Jolly, Markus Pangerl, Ashwin Raj, Carlos Perera, Luisa Tora, and two anonymous reviewers, who have all commented helpfully on earlier drafts of this paper. Thanks also to Lia Szokalski and Michelle Antoinette for their help in the editing process. Fieldwork funding for this research was provided by Department of International Relations in the Research School of Pacific and Asian Studies at the Australian National University.

\section{Notes}

I Other states that provide their citizens with constitutional protection against discrimination on the basis of sexual orientation are South Africa since I996, Ecuador since 1998, and Switzerland since 1999. (For details of constitutional law and domestic statutes that prohibit discrimination on the basis of sexual orientation, see the International Lesbian and Gay Association's "World Legal Survey" [ILGA 2002].)

2 For detailed accounts of the Fiji Constitution Review Commission hearings and the drafting process, see Lal 2002, 2003; and Norton 2000.

3 The conceptual approach to masculinity I employ in this article draws on $\mathrm{R}$ W Connell's theoretical work on the relations between masculinities and the ways in which social structures-class, race, or material-contribute to certain forms of masculinity becoming hegemonic and others subordinate. As Connell stated, "It is the successful claim to authority, more than direct violence, that is the mark of hegemony" and that sustains the relationship between hegemonic and subordinate masculinities $(2005,77)$.

4 See Herdt I98I, I984, I994, I997; Besnier 1994; Allen 1984; Schmidt 2003; McIntosh 1999; Aldrich 2003.

5 In an article examining this practice in Polynesia, Niko Besnier described gender liminality as the "adoption by certain individuals of attributes associated with gender other than their own" and contends that this is an activity "deeply embedded in the dynamics of Polynesian cultures and societies" (I994, 285).

6 Besnier cited a range of contexts in which the occurrence of homosexual behavior between young men is "well known" and seemingly accepted. He argued that in Fiji homosexuality is generally viewed to be prevalent in British-style elite private schools and prisons and that students and ex-prisoners are frequently "chided about their homosexual encounters" (Besnier I 994, 299).

7 Joanna Schmidt contended that the introduction of capitalism to Sāmoa has 
encouraged individuation in the traditional group-oriented society and weakened the significance of gender-defined roles, as women and men are engaged in wage-earning labor (2003). Samoan fa'afafine have traditionally defined themselves through their feminine labor role, and been valued in social contexts where resources and labor were pooled. But Schmidt has suggested that, in the contemporary setting, fa'afafine struggle to define their place, as gender is increasingly likely to be expressed "through individually embodied sexuality," and labor roles within the family are no longer the predominant markers of gender that they have been in the past $(2003,420-42 \mathrm{I})$.

8 In addition to hearing more than seven hundred local submissions, the Fiji Constitution Review Commission also chose to examine the experiences of constitution drafting in other states and to consider internationally recognized standards and principles that protected group and minority rights (Lal 2002, I 5 I). Examination of the provisions in South Africa's post-apartheid constitution illustrated how the issue of sexual minority rights was dealt with in a recently drafted national bill of rights. The commissioners were also aware that international human rights norms during this period were increasingly interpreted in ways that viewed discrimination on the basis of sexual orientation as a human rights violation (during this period the United Nations Human Rights Committee declared reference to sex in Article 2 [I] of the Universal Declaration of Human Rights to include "sexual orientation"). In the words of one former commissioner, sensitivity to the rights of sexual minorities was becoming "part of the global consciousness" (Lal, pers comm 2005). The suggestion being that it was simply a matter of course to include protection of these rights in Fiji's new constitution, in line with international political developments and the progressive nature of South Africa's constitution.

9 These charges were found to be inconsistent with Fiji's constitutional provisions regarding the right to privacy.

Io International media attention was widely focused on the McCoskar case in Fiji and the ensuing wave of negative political sentiment evident in comments made by a range of political and religious leaders on the issue of homosexuality in Fiji. This situation enabled Samson Verma, a Fijian citizen living illegally in France, to successfully win a claim for political asylum in the French courts on the basis that as a homosexual he faced widespread persecution should he be forced to return to his country of birth (Silberfield 2005).

I I However, as Jacqueline Ryle noted (2005), the influence of Pentecostal churches is also increasing in Fiji. As shown in this article, members of mainstream and Pentecostal churches have tended to close ranks on the issue of homosexuality in Fiji and together have articulated strongly conservative opposition to the 1997 constitutional provisions. Both groups have also supported calls for Fiji to declare itself a Christian state (Ryle 2005, 6I). Yet, as Ryle noted, there are also significant differences between followers of the Pentecostal churches and those 
of the numerically predominant Methodist faith. While Fijian Methodists hold a "static and uncritical image of the past and tradition" and believe in the need to uphold a chiefly system of authority intertwined with Church values, Pentecostalists are more critical of the "lack of clear separation between tradition and faith" that is evident in Fiji's Methodist church (Ryle 2005, 6I-62). Ryle's findings suggest that for Pentecostalist believers, the idea of a harmonious tripartite union between vanua, lotu, and matanitu is problematic.

I 2 Ryle demonstrated that certain members of the Methodist church have assessed these calls in more critical terms (2005). She noted that the Reverend Dr Tuwere described the supposed harmony between lotu and vanua as a romanticized image that "glosses over" the realities of "poverty and injustice in Fiji," and quoted the Reverend Josateki Koroi, who argued that the ideals of vanua and lotu are used by indigenous political actors to "exploit and dominate others" (Ryle $2005,72)$.

I 3 This emphasis is clearly indicated by the interim government's decision to create a Ministry of Reconciliation, ostensibly to improve relations between Fiji's ethnic communities (Daily Post, 2 April 2002).

I4 Feelings of insecurity were widespread in Fiji during this period and experienced with particular urgency among the Indo-Fijian population (Emde 2005). John Kelly and Martha Kaplan contended that Indo-Fijian political leaders were barely heard during this period, and that their demands were generally ignored by indigenous actors and the media (200I). Ultimately the Indo-Fijian community appears to have deemed it prudent to avoid overt political confrontation with the ethno-nationalist insurgents. Noting that Fiji's passport office ran out of forms in the months following the coup, Kelly and Kaplan suggested that for many, "emigration remained a major vehicle for exercising political will” (200I, I 86).

I 5 This suspect was later found to be mentally unfit to stand trial, with the result that the allegations were never substantiated.

I 6 Indeed, international media commentators began to question the closeness of the Fiji media's relationship to the police in reporting of this incident. It was argued that local reports tended to be unbalanced, sensationalized, based on hearsay, and in some cases "violated legal principles of contempt of court and sub judice" (Robie 2003, 4).

I7 For a comparative study of violence perpetrated by and against homosexuals of European and Melanesian origin in Papua New Guinea and Solomon Islands during colonial periods, see Aldrich 2003.

I 8 See, eg, Fiji Times, 7 Dec, 9 Dec, 26 Dec 2006; Fiji Times 3 Jan, 8 March 2007; Fijilive, 23 Jan 2007; Fiji Post, 6 Dec 2006; Fiji Sun, 27 Dec 2006.

I9 See "Alleged Human Rights Abuses, Constitutional Violations and Breaches of the Rule of Law in relation to the Coup d'Etat of 5 th December 2006," a document circulated via electronic networks in January 2007; online at http://www 
.defendingwomen-defendingrights.org/pdf2007/Updated 260 107Monitoring _FijiCoup2006Longversion.pdf [accessed I July 2007]

20 These include the Fiji Women's Rights Movement, Pacific Centre for Public Integrity, Fiji Women's Crisis Centre, Fiji Law Society, fem'Link Pacific, Fiji Disabled Peoples Association, and the Pacific Network on Globalisation.

2I The most prominent of these are Women's Action for Change and the Ecumenical Centre for Research, Education, and Advocacy.

22 For an interesting commentary on the ways in which the December 2006 coup can also be read as a challenge to indigenous chiefly authority see analysis provided by Graham Davis in The Australian, 6 January 2007.

\section{References}

Aldrich, Robert

2003 Colonialism and Homosexuality. London: Routledge.

Allen, Michael R

I984 Homosexuality, Male Power and Political Organization in North Vanuatu: A Comparative Analysis. In Ritualized Homosexuality in Melanesia, edited by Gilbert Herdt, 83-I 27. Berkeley: University of California Press.

The Australian. Daily newspaper. Sydney. http://www.theaustralian.news.com .au/

Bainimarama, Voreqe

2006 Statement of Fiji Commander Bainimarama. Press statement, 5 December. Archived online by Pacific Islands Report http://archives.pireport .org/archive/2006/december/I $2 \%$ 2D I $2 \%$ 2Dsti.htm [accessed I I April 2007]

Besnier, Niko

I994 Polynesian Gender Liminality through Time and Space. In Ritualized Homosexuality in Melanesia, edited by Gilbert Herdt, 285-328. Berkeley: University of California Press.

Carling, Mere, and Colleen Peacock-Taylor

$200 \mathrm{I}$ Study of the Impacts of the Political Crisis on Children and Families in Fiji. Suva: Save the Children.

Connell, R W

2005 Masculinities. Second edition. Berkeley: University of California Press.

Cretton, Viviane

2005 Traditional Apology as a Fijian Strategy. Oceania 75 (4): 403-4I7.

Daily Post. Suva. Newspaper. http://www.fijidailypost.com/

Davis, Graham 2007 It's Hail to the Chief No Longer. The Australian, 6 January. 
Durutalo, Alumita

I997 Provincialism and the Crisis of Indigenous Fijian Political Unity. MA Thesis, Centre for Development Studies, University of the South Pacific.

Emde, Sina

2005 Feared Rumours and Rumours of Fear: The Politicisation of Ethnicity during the Fiji Coup in May 2000. Oceania 75 (4): 387-402.

Field, Michael

2002 Pacific Mainline Christianity Succumbing to New Influences. Agence France-Presse, I I June. Archived online by Pacific Islands Report http://archives.pireport.org/archive/2002/june/06\% 2D I $2 \% 2 D_{3} . h t m$ [accessed 28 October 2005]

Fijilive. Online news service. http://www.fijilive.com/

Fiji Sun. Daily newspaper. Suva. http://www.sun.com.fj/

Fiji Times. Daily newspaper. Suva. http://www.fijilive.com/

Fraenkel, John

2000 The Clash of Dynasties and Rise of Demagogues: Fiji's Tauri Vakaukauwa. The Journal of Pacific History 35 (3): 295-308.

Fry, Greg

2000 Political Legitimacy and the Post-Colonial State in the Pacific: Reflections on Some Common Threads in the Fiji Islands and Solomon Islands Coups. Pacifica Review: Peace, Security and Global Change [La Trobe University] I 2 (3): 295-304.

Goodwillie, Dianne, and Ruth Lechte

I985 Women and Development Programs in the Pacific. In From Rhetoric to Reality? Papua New Guinea's Eight Point Plan and National Goals After a Decade; Papers from the Fifteenth Waigani Seminar, edited by P King, W Lee, and V Warakai, 58-65. Port Moresby: Papua New Guinea Press.

Griffen, Vanessa

I984 The Pacific Islands: All It Requires is Ourselves. In Sisterhood is Global: The International Women's Movement Anthology, edited by Robin Morgan, 517-524. New York: Anchor Books.

I987 Women, Development and Empowerment: A Pacific Feminist Perspective. Report of a Pacific Women's Workshop, Naboutini, Fiji, 23-26 March 1986. Kuala Lumpur: Asian and Pacific Development Centre.

Herdt, Gilbert

I98 I Guardians of the Flutes: Idioms of Masculinity. New York: McGrawHill.

I984 Ritualized Homosexual Behavior in Male Cults of Melanesia, I862I983: An Introduction. In Ritualized Homosexuality in Melanesia, 
edited by Gilbert Herdt, I-8I. Berkeley: University of California Press.

I994 Introduction: Third Sexes and Third Genders. In Third Sex, Third Gender: Beyond Sexual Dimorphism in Culture and History, edited by Gilbert Herdt, 2 I-8 I. New York: Zone Books.

I997 Same Sex, Different Culture. Boulder, co: Westview Press.

Hereniko, Vilsoni

2003 Interdisciplinary Approaches in Pacific Studies: Understanding the Fiji Coup of I9 May 2000. The Contemporary Pacific I 5:75-90.

ILGA, International Lesbian and Gay Association

2002 World Legal Survey. 30 September. Online at http://www.ilga.info/ Information/Legal_survey/list_of_international_treaties.htm [accessed 2 June 2006]

Kaplan, Martha

2005 The Hau of Other Peoples' Gifts: Land Owning and Taking in Turn of the Millennium Fiji. Ethnohistory 52 (I): 29-46.

Kelly, John, and Martha Kaplan

200I Represented Communities: Fiji and World Decolonization. Chicago: University of Chicago Press.

Lal, Brij V

2002 Making History, Becoming History: Reflections on Fiji's Coups and Constitutions. The Contemporary Pacific I4: I48-167.

2003 Fiji's Constitutional Conundrum. The Round Table 372 (October): $67 \mathrm{I}-685$.

McIntosh, Tracey

I999 Words and Worlds of Difference: Homosexualities in the Pacific. Sociology and Social Policy Working Paper 3/99. Suva: The University of the South Pacific.

Monsell-Davis, Michael

2000 Social Change, Contradictions, Youth and Violence in Fiji. In Reflections on Violence in Melanesia, edited by Sinclair Dinnen and Alison Ley Hawkins, 209-222. Canberra: Press/Leichhardt and Asia Pacific Press.

Niukula, Paula

I997 Religion and the State. In Fiji in Transition, edited by Brij V Lal and Tomasi R Vakatora, 53-79. Vol I, Research Papers of the Fiji Constitution Review Commission. Suva: School of Social and Economic Development, The University of the South Pacific.

Norton, Robert

2000 Reconciling Ethnicity and Nation: Contending Discourses in Fiji's Constitutional Reform. The Contemporary Pacific I 2:83-I 22. 
NZ AIDs, New Zealand AIDs Foundation

2005 Church Decision to Listen to Gays Welcomed. Press Release, 2 November.

Pacific Islands Report. Online news service. http://pidp.eastwestcenter.org/ pireport/

Radio Australia. Australian Broadcasting Corporation. http://www.abc.net.au/ $\mathrm{ral}$

Radio New Zealand International. http://www.radionz.co.nz/

Robertson, Robbie, and William Sutherland

2001 Government by the Gun: The Unfinished Business of Fiji's 2000 Coup. Annandale, Nsw: Pluto Press.

Robie, David

2003 Pacific Media Councils and Cultural Values: Safety Valve or Entrenched Hegemony? Paper delivered to "Between Empires: Communication, Globalisation and Identity Conference," held at the School of Communication Studies, Auckland University of Technology, I3-I 5 February. Online at http://www.asiapac.org.fj/cafepacific/resources/aspac/ medcouncilso3.pdf [accessed 5 June 2006]

Ryle, Jacqueline

2005 Roots of the Land and Church: The Christian State Debate in Fiji. International Journal for the Study of the Christian Church 5 (I): 58-78.

Schmidt, Joanna

2003 Paradise Lost? Social Change and Fa'afafine in Samoa. Current Sociol-

Scott, Owen ogy 5 I $(3 / 4): 4$ I $7-432$.

2004 Deep Beyond the Reef: A True Story of Madness and Murder in the South Pacific. Albany, NZ: Penguin.

Silberfield, Judith

2005 L'asile accordé par la France à un gay fidjien fait des ramous. Têtu: Le Magazine des Gays et des Lesbiennes, 24 January. Online at http:// www.tetu.com/rubrique/infos/infos_detail.php?id_news=892\&date_ info $=2005$-OI-24 [accessed I I April 2007]

Slatter, Claire

2006 Treading Water in Rapids? Non-Governmental Organizations and Resistance to Neoliberalism in Pacific Islands States. In Globalisation and Governance in the Pacific Islands, edited by Stewart Firth, 23-42. Canberra: ANU E Press.

Strubbe, Bill, and Luisa Tora

2002 Gay Fiji-Murder in Paradise. Out Magazine, January. Online at http:// www.globalgayz.com/g-fiji.html [accessed 29 May 2006]

Sydney Morning Herald. Daily newspaper. http://www.smh.com.au/ 
Tarte, Sandra

200I Melanesia in Review: Issues and Events: Fiji. The Contemporary Pacific I 3:529-54I.

Teaiwa, Teresia

2005 Articulated Cultures: Militarism and Masculinities in Fiji during the Mid I990s. Fijian Studies 3 (2): 201-222.

Tuwere, Ilaitia Sevati

I997 The Church-State Relation in Fiji. In Fiji in Transition: edited by Brij V Lal and Tomasi R Vakatora, 44-52. Vol I, Research Papers of the Fiji Constitution Review Commission. Suva: School of Social and Economic Development, The University of the South Pacific.

WAC/sm, Women's Action for Change, Sexual Minorities project 2005 a Public Statement, 3 I August.

2005b Press Release, 3 September.

\section{Abstract}

Despite the fact that Fiji is one of only a handful of states to have given constitutional recognition to the rights of sexual minorities in its most recent constitution enacted in 1998 , controversy over the issue of individual sexual orientation, and powerful condemnation of those who choose to publicly demonstrate a homosexual or transgender identity, has flourished in the public domain. The focus on male homosexuality has been predominant in this debate, with many influential political actors framing discourses of masculinity in ways that affirm Christian ideals of morality while also reinforcing the Christian Church's normative political authority. However, as this article demonstrates, public discourses of masculinity have also been articulated in a highly selective manner. This becomes clear when public debate that construes homosexuality in Fiji as a threat to the integrity of the country's key social institutions is contrasted with some church and political leaders' far more lenient responses to the forms of violent and lawless masculine behavior that predominated during the 2000 coup. While these developments have increased the political and social vulnerability of Fiji's homosexuals, young gay men have also employed strategies that contest mainstream discriminatory attitudes. In this article, I describe how the terrain of sexual minority politics is configured in ways that authorize certain varieties of masculine behavior and subordinate others, and consider the strategies deployed by local gay males to contest homophobic sentiments articulated in the public domain.

KEYWORDS: masculinities, homosexuality, nationalism, Christianity, Fiji 